\title{
The phanerozoic diversity of agglutinated foraminifera: Origination and extinction rates
}

\author{
Michael A. Kaminski, Eiichi Setoyama, and Claudia G. Cetean \\ Acta Palaeontologica Polonica 55 (3), 2010: 529-539 doi: http://dx.doi.org/10.4202/app.2009.0090
}

New diversity curves for agglutinated foraminiferal genera are presented based on the stratigraphic ranges of 764 genera distributed over the 91 Phanerozoic chronostratigraphic subdivisions given in the ICS timescale. The data set for this analysis is based on the stratigraphic ranges of agglutinated genera published in Foraminiferal Genera and their Classification , 218 of which have been modified based upon subsequently published studies and new observations. Additionally, a total of 136 genera have been newly described or reinstated subsequent to the publication of Foraminiferal Genera and their Classification. The revision of stratigraphic ranges is part of the effort by the Grzybowski Foundation's International Working Group on Foraminiferal Classification to compile a new Catalogue of Agglutinated Foraminiferal Genera. The mean standing diversity of agglutinated foraminiferal genera was compiled by counting the number of boundary crossers rather than the number of genera in each stage. This diversity curve displays a general upward trend throughout the Phanerozoic, punctuated by peaks and troughs of variable magnitude. The curve shows a period of initial radiation from the Early Cambrian to the Early Silurian, followed by a plateau to the Late Permian. The Permian/Triassic and the Triassic/Jurassic boundaries are characterised by small dips in the diversity record. The Jurassic begins with an exponential rise in mean standing diversity that continues to the Cenomanian. The Cenomanian to Holocene record of mean standing diversity is characterised by four peaks and troughs that are roughly in line with the cycles of global climate, with reductions in diversity in the end-Cenomanian, end-Cretaceous, and end-Miocene. Excluding modern values, the Phanerozoic maximum in the number of genera with a fossil record is observed in the Cenomanian, whereas the maximum Phanerozoic mean standing diversity is observed in the Langhian stage of the Miocene. The highest per-capita origination rates are observed in the Hettangian, Dapingian, Pleistocene, and Sheinwoodian (mid-Silurian). Linear regression analysis of the origination rates reveals a decrease towards the Holocene, in agreement with findings of Raup and Sepkoski. The highest per-capita extinction rates are observed in the Messinian, late Silurian (Gorstian), Hirnantian (latest Ordovician), and Maastrichtian. The background extinction rate shows an increasing trend towards the Recent, which is in disagreement with the findings of Raup and Sepkoski. We attribute this apparent discrepancy to the Late Cretaceous to Palaeogene extinctions of shallower-water larger agglutinates and the pull of the end-Miocene extinction event.

Key words: Agglutinated foraminifera, phanerozoic, biodiversity, extinction, origination. 
Michael A. Kaminski [m.kaminski@ucl.ac.uk], Department of Earth Sciences, University College London, Gower Street, London WC1E 6BT, UK; Earth Sciences Department, King Fahd University of Petroleum and Minerals, Dhahran 31261, Saudi Arabia; Eiichi Setoyama [ndsetoya@cyf-kr.edu.pl], and Claudia G. Cetean [ndcetean@cyf-kr.edu.pl], Institute of Geological Sciences, Polish Academy of Sciences, ul. Senacka 1, 30-002 Kraków, Poland.

This is an open-access article distributed under the terms of the Creative Commons Attribution License (for details please see creativecommons.org), which permits unrestricted use, distribution, and reproduction in any medium, provided the original author and source are credited.

Forif $\underline{\text { Full text }(400.7 \mathrm{kB})}$ 